\title{
The effect of iron supplementation in the diet of Dasypus novemcinctus (Linnaeus, 1758) armadillos in captivity
}

\author{
Rosa, PS. ${ }^{\text {* }}$, Pinke, CAE. ${ }^{\mathrm{b}}$, Pedrini, $S C B .^{\mathrm{a}}$, Silva, EA. ${ }^{\mathrm{a}}$ \\ anstituto Lauro de Souza Lima, \\ Rodovia Comandante João Ribeiro de Barros, Km 225, CP 3021, CEP 17034-971, Bauru, SP, Brazil \\ 'Instituto Brasileiro de Meio Ambiente, \\ Av. Cruzeiro do Sul, nº 25/16, Jardim Carolina, CEP 17032-000, Bauru, SP, Brazil \\ *e-mail prosa@ilsl.br \\ Received December 12, 2006 - Accepted May 25, 2007 - Distributed February 28, 2009
}

\begin{abstract}
Armadillos of the species Dasypus novemcinctus have been used as an experimental model of leprosy. Besides nonhuman primates, they are the only species naturally infected with Mycobacterium leprae and when experimentally inoculated, reproduce the lepromatous form of the disease producing large quantities of bacilli. This species has been maintained in captivity by numerous researchers and specific housing and feeding requirements have been developed to guarantee their survival during long experimental periods. In the "Lauro de Souza Lima" Institute, armadillos receive dog food, ground beef, boiled eggs and vitamin C. However, despite the balanced diet, anemia has been observed in some captive animals, especially in armadillos inoculated with $M$. leprae in advanced stages of infection. Thus, the objective of the present study was to evaluate the effect of iron sulfate supplementation in the feed provided for armadillos, both inoculated and non-inoculated with M. leprae, by means of the evaluation of their hematological profile. Fourteen armadillos received $10 \mathrm{mg} / \mathrm{animal}$ of iron sulfate $\left(\mathrm{Hematofer}^{\circledR}\right)$ diluted in sterile water mixed with their daily feed for 50 days. Hemograms and serum iron dosages for each armadillo were performed before and after supplementation. The hematocrit values increased significantly after iron supplementation, both in armadillos inoculated and non-inoculated with M. leprae. It is possible that the amount of iron in the feed is insufficient for the formation of hemoglobin, leading to microcytic anemia. Dietary supplementation with iron sulfate reversed this state, showing the importance of understanding the metabolism of exotic species for their maintenance in captivity, and thus ensuring their well-being.
\end{abstract}

Keywords: Dasypus novemcinctus, hematological profile, armadillos, iron supplementation, Mycobacterium leprae.

\section{$O$ efeito da suplementação com ferro na dieta de tatus Dasypus novemcinctus (Linnaeus, 1758) em cativeiro}

\section{Resumo}

O tatu da espécie Dasypus novemcinctus tem sido utilizado como modelo experimental para a hanseníase. Eles são a única espécie, além de primatas não humanos, que se apresentam naturalmente infectados pelo Mycobacterium leprae. Estes tatus, quando experimentalmente inoculados, reproduzem a forma virchoviana da hanseníase produzindo grandes quantidades de bacilos. Esta espécie tem sido mantida em cativeiro por vários pesquisadores, no entanto, alguns cuidados são necessários para garantir a sobrevivência destes por longos períodos experimentais, tais como alojamento e alimentação. No Instituto Lauro de Souza Lima, os animais em cativeiro recebem ração canina, carne bovina, ovos cozidos e vitamina $\mathrm{C}$, mesmo assim, tem-se observado o desenvolvimento de quadros de anemia nestes animais, principalmente nos inoculados com o M. leprae, em estados avançados da infecção. Sendo assim, o objetivo deste estudo foi avaliar o efeito da suplementação com sulfato ferroso na alimentação fornecida aos tatus, inoculados e não inoculados com M. leprae, por meio de avaliação de seu perfil hematológico. Foram utilizados 14 animais que receberam $10 \mathrm{mg} /$ animal de sulfato ferroso $\left(\mathrm{Hematofer}^{\circledR}\right)$ diluídos em água estéril e misturados diariamente à ração por 50 dias. Foram feitos hemograma e dosagem de ferro sérico de cada animal antes e após a suplementação. Os valores de hematócrito aumentaram significativamente após a suplementação, tanto nos animais inoculados como nos não inoculados com M. leprae. É possível que a quantidade de ferro na alimentação seja insuficiente para a formação da hemoglobina, levando a um quadro de anemia microcítica. A suplementação da dieta com sulfato ferroso reverteu este quadro, mostrando a importância de se conhecer o metabolismo de espécies exóticas para manutenção destas em cativeiro, assegurando seu bem estar.

Palavras-chave: Dasypus novemcinctus, perfil hematológico, tatus, suplementação com ferro, Mycobacterium leprae. 


\section{Introduction}

The nine-banded armadillo Dasypus novemcinctus belongs to the family Dasypodidae, Order Cingulata which, together with anteaters and sloths, comprises the Superorder Xenarthra (Gardner, 2005). Climate and seasonality interfere in the activity of the armadillo, which is most active at dusk and during the night, in order to avoid predators and extremes of temperature (Storrs and Bucherfield, 1985; Wetzel, 1985). Some armadillos are basically insectivores, preferring ants and termites, however, many species like the genus Dasypus also feed on fruits, roots and small vertebrates (McDonough and Loughry, in press). Armadillos swallow their prey without chewing it together with soil particles. Through analysis of the stomach contents of this species, Laguna (1984) and Superina (2000) observed that the natural diet of D. novemcinctus consisted of about $70.8 \%$ insects, $7 \%$ other invertebrates, $13.2 \%$ vertebrates (amphibians and reptiles) and $9 \%$ plant material.

Armadillos are known to harbor several pathogens, such as Trypanossoma cruzi, Toxoplasma gondii, species of Sarcocystis and Eimeria, Piroplasma (Diniz et al., 1997), Leptospira sp., Sporothrix schenckii, Paracoccidioides brasiliensis (Naiff et al., 1986; SilvaVergara, 1997; Bagagli et al., 1998; Macedo, 1999; Vergara and Martinez, 1999) and Mycobacterium leprae (Truman, in press), though the zoonotic transmission potential of these microorganisms has not yet been clarified.

Because armadillos present a low body temperature $\left(32-35^{\circ} \mathrm{C}\right)$ and a mean lifespan of 12 to 15 years in nature, the species $D$. novemcinctus has been used as an experimental model for leprosy (Storrs, 1971). Besides non-human primates, they are the only species naturally infected with $M$. leprae and when experimentally inoculated, reproduce the lepromatous form of the disease producing large quantities of bacilli. Nowadays, armadillos have been used for in vivo propagation of $M$. leprae and development of diagnostic reagents and vaccines. (Truman, in press)

In patients with lepromatous leprosy, anemias occur due to chronic disease that is secondary to the infectious inflammatory process and it is associated with the reactional states of the disease, mainly in erythema nodosum leprosum (Saxena et al., 1990; Freitas and Fleury, 1996). This type of anemia is mediated by cytokines and is characterized as light or moderate, hypochromic microcytic with hematocrits around $30 \%$. No references exist regarding the development of anemia symptoms in armadillos after inoculation with $M$. leprae (Storss et al., 1974; McDonough, 1997; Truman, in press). However, it can be inferred that inoculated armadillos would present similar hematological alterations to those found in diseased humans, either through the infectious process (hepatic problems) or by organ failure resulting from the dissemination of the disease.

Since the mid-1970s, armadillos have been maintained in laboratory conditions for leprosy research purposes in the "Lauro de Souza Lima" Institute (ILSL) (Opromolla et al., 1980, Arruda and Opromolla, 1981, Rosa et al., 2005a; 2005b; Pedrini et al., 2006). The armadillos are captured in the wild and placed in individual pens with water ad libitum and feed provided once a day. The majority of the armadillos adapts well to the captive conditions and accepts the artificial diet immediately. A small percentage of armadillos requires time for adaptation and are offered an initial diet consisting of ground beef and boiled eggs, with canine food introduced into the diet a little at a time. However, some do not adapt to captivity and die within a few days.

In contrast to their natural diet, armadillos do not have access to a varied diet in captivity. Since the Experimentation Animal Laboratory for armadillos was established, several diets have been tested (Arruda and Opromolla, 1981), but the diet that has best supplied the requirements of the species in our laboratory conditions is based on canine food supplemented with beef, eggs and vitamin C (Superina, 2000). However, as they have no direct access to the soil, the armadillos may suffer from deficiencies in the absorption and/or metabolism of iron, as indicated by our experience with animals presenting anemia symptoms when submitted to stressful conditions and natural or experimental diseases. Similarly, Robbins (1992) observed that iron deficiencies are relatively common in animals maintained in zoological gardens, particularly young hand-reared individuals.

Because the nine banded armadillo is the primary animal for research at the ILSL, this justifies studying its hematological profile. The aim of this study was to evaluate the effect of iron sulfate supplementation in the feed provided for armadillos maintained in captivity, both inoculated and non-inoculated with $M$. leprae, by examining the hematological profile of these animals.

\section{Materials and Methods}

\subsection{Animals and maintenance}

D. novemcinctus armadillos were captured in the region of Bauru, São Paulo state (SP), Brazil, during the period from September, 2000 to November, 2004, and maintained in the Animal Experimentation Laboratory of the ILSL, Bauru, SP, Brazil (Maintenance License for Scientific Purpose, IBAMA, Registration 1/35/1999/000230-0). Each armadillo was individually housed in a brick pen $(1 \times 1.2 \mathrm{~m})$ provided with a polystyrene box filled with dry grass and with water ad libitum. The spaces were acclimatized to $25^{\circ} \mathrm{C}$, with artificial lighting ( 8 hours light/16 hours darkness). The armadillos studied had been in captivity for at least four months before the start of the study. A total of 14 adult armadillos were used, nine inoculated ( 7 males and $2 \mathrm{fe}-$ males) with $M$. leprae and five non-inoculated ( 3 males and 2 females), with live weight (LW) varying between 3.2 and $5.0 \mathrm{~kg}$. 
The feed provided to the armadillos comprised $1.1 \mathrm{~kg}$ of Special Club HE ${ }^{\circledR}$ Royal Canin canine feed (for pregnant and/or milking female dogs) softened in warm water, 3 boiled chicken eggs with shells, vitamin C ( $200 \mathrm{mg} / \mathrm{animal} / \mathrm{day}$ ) and around $270 \mathrm{~g}$ of minced beef. Each animal was fed about $200 \mathrm{~g}$ of this mixture each day.

\subsection{Dietary supplementation}

The quantity of iron sulfate provided daily to the armadillos through their feed was estimated as: $149 \mathrm{mg} \cdot \mathrm{kg}^{-1}$ in the canine feed, $1.1 \mathrm{mg} /$ whole egg and $470 \mathrm{mg} \cdot \mathrm{kg}^{-1}$ of minced beef, which resulted in around $294.1 \mathrm{mg}$ of iron in the total feed or $14.5 \mathrm{mg} / \mathrm{animal}$. Since no data exists regarding the nutritional requirements of iron for D. novemcinctus armadillos, nor for any other species of the same genus or family, the daily iron requirement of numerous monogastric species were compared to best determine the amount that should be provided for the armadillos. Each animal thus received $10 \mathrm{mg}$ of iron sulfate $\left(\right.$ Hematofer $\left.^{\circledR}\right)$ diluted in sterile water and mixed into the daily feed for 50 days.

\subsection{Clinical and laboratory evaluation}

The armadillos were observed daily and evaluated regarding their physical and behavioral conditions. The armadillos were submitted to chemical restraint to obtain blood samples. Pre-medication with atropine sulfate (0.044 mg. $\mathrm{kg}^{-1}$ of LW, subcutaneous via) was followed by anesthesia with tiletamine and zolazepam $\left(5.0 \mathrm{mg} \cdot \mathrm{kg}^{-1}\right.$ of LW, intramuscular via). Blood samples were obtained from the subclavian vein.

Hematological values were determined before and after 50 days of dietary supplementation with iron sulfate. The hematological analysis was carried out using an Autolyzer, model AL-818 (AVL List Gmbh, Austria). Differential counts for leukocytes were performed with an optic microscope from blood smears.

\subsection{Statistical analysis}

Paired $t$ test was used to compare different variables for inoculated and non-inoculated groups before and after iron sulfate supplementation at a $5 \%$ significance level.

\section{Results}

Clinically the armadillos were healthy, with pink mucosas and shiny carapaces. Their feces remained firm throughout the evaluation period. Behavior of the animals did not change. Before the experiment animals were already adapted to captivity and remained vigilant and active during feeding period (mid-morning) and at night, throughout and after the period of supplementation.

The means of the values obtained in the complete hemograms of the armadillos inoculated and noninoculated with $M$. leprae are presented in Table 1. Before and after

Table 1. Hematological parameters and serum iron dosage in armadillos non-inoculated $(n=5)$ and inoculated $(n=9)$ with M. leprae, before and after oral supplementation with iron sulfate.

\begin{tabular}{|c|c|c|c|c|}
\hline \multirow[t]{2}{*}{ Parameters } & \multicolumn{2}{|c|}{$\begin{array}{c}\text { Non-inoculated armadillos } \\
(\text { mean } \pm \text { SD) }\end{array}$} & \multicolumn{2}{|c|}{$\begin{array}{l}\text { Armadillos inoculated with } M \text {. leprae } \\
(\text { mean } \pm \text { SD) }\end{array}$} \\
\hline & Before $\mathrm{FeSO}_{4}$ & After $\mathrm{FeSO}_{4}$ & Before $\mathrm{FeSO}_{4}$ & After $\mathrm{FeSO}_{4}$ \\
\hline \multicolumn{5}{|l|}{ Erythrogram } \\
\hline Erythrocytes $\left(10^{6} \cdot \mathrm{mL}^{-1}\right)$ & $6.51 \pm 0.35$ & $4.62 \pm 0.37 *$ & $5.37 \pm 1.44$ & $4.36 \pm 0.42$ \\
\hline Hemoglobin $\left(\mathrm{g} \cdot \mathrm{dL}^{-1}\right)$ & $10.84 \pm 1.43$ & $13.68 \pm 1.24^{*}$ & $8.71 \pm 3.21$ & $12.82 \pm 1.4 *$ \\
\hline Hematocrits (\%) & $36.20 \pm 1.64$ & $41.20 \pm 3.70^{*}$ & $30.02 \pm 8.65$ & $38.56 \pm 4.25^{*}$ \\
\hline Globular volume $\left(\mu^{3}\right)$ & $55.60 \pm 0.72$ & $89.12 \pm 0.95^{*}$ & $55.57 \pm 2.03$ & $88.41 \pm 1.23^{*}$ \\
\hline $\mathrm{MCH}(\mathrm{pg})$ & $16.62 \pm 1.85$ & $29.6 \pm 0.35^{*}$ & $15.83 \pm 2.31$ & $29.42 \pm 0.37 *$ \\
\hline $\mathrm{MCHC}(\%)$ & $29.92 \pm 3.45$ & $33.2 \pm 0.07$ & $28.43 \pm 3.60$ & $33.27 \pm 0.05^{*}$ \\
\hline \multicolumn{5}{|l|}{ Leukogram } \\
\hline Leukocytes (/mL) & $6180.00 \pm 2092.13$ & $4560.00 \pm 1132.70 *$ & $4511.11 \pm 2852.83$ & $5222.22 \pm 2038.86$ \\
\hline Neutrophils (\%) & $38.20 \pm 7.49$ & $43.20 \pm 10.61$ & $42.67 \pm 5.81$ & $45.44 \pm 7.95$ \\
\hline Rods (\%) & $6.40 \pm 0.89$ & $6.4 \pm 1.67^{\#}$ & $3.00 \pm 2.45$ & $5.56 \pm 2.19 *$ \\
\hline Segmented cells $(\%)$ & $31.80 \pm 7.82$ & $36.80 \pm 9.28$ & $39.67 \pm 6.73$ & $39.89 \pm 6.85$ \\
\hline Eosinophils (\%) & $15.40 \pm 4.50$ & $13.00 \pm 2.55$ & $10.44 \pm 9.02$ & $11.33 \pm 2.83$ \\
\hline Lymphocytes (\%) & $38.00 \pm 11.42$ & $36.40 \pm 8.47$ & $40.11 \pm 10.12$ & $36.67 \pm 9.90$ \\
\hline Monocytes (\%) & $8.40 \pm 0.89$ & $7.40 \pm 1.34$ & $6.78 \pm 2.91$ & $6.56 \pm 1.94$ \\
\hline Serum iron $\left(\mu \mathrm{g} . \mathrm{dl}^{-1}\right)$ & $180.95 \pm 47.14$ & $176.89 \pm 81.91$ & $233.86 \pm 43.15$ & $200.67 \pm 48.02$ \\
\hline
\end{tabular}

Statistical analysis using the Student $t$ test $(\mathrm{p}<0.05)$ : *indicates a significant difference before and after oral supplementation with $\mathrm{FeSO}_{4}$; \# indicates a significant difference between the groups of inoculated and non-inoculated armadillos; $\mathrm{MCH}$, mean corpuscular hemoglobin; $\mathrm{MCHC}$, mean corpuscular hemoglobin concentration. 
iron sulfate supplementation, significant differences were found in erythrocytes, hemoglobin, hematocrit, globular volume, mean corpuscular hemoglobin and leucocytes of the non-inoculated group of armadillos. In animals inoculated with $M$. leprae, all erythrogram parameters, except for total erythrocytes count, were significantly different before and after iron supplementation.

\section{Discussion}

Iron is essential for the majority of animals and it is present in all the cells of living organisms, mainly in the form of complexes linked to proteins. Since it is indispensable for the constitution of hemoglobin, iron plays a fundamental role in hematopoiesis. The totality of hemoglobin in an organism is found in the blood, particularly in the erythrocytes. Normally the concentration and the total capacity of iron linkage vary according to species, gender, age, nutritional status and pregnancy (Kaneko, 1980). In newborn animals a minimum iron reserve is found at the end of the suckling period due to depletion of the iron reserves and the lack of this element in milk. Certain mammals, such as rabbits, are born with an important reserve of this element, while others, such as pigs, are born with poor reserves (Andriguetto et al., 1988). The organisms of adult animals contain between 2.5 and $4.0 \mathrm{~g}$ of iron, with around $60-70 \%$ circulating as a component of hemoglobin, $10 \%$ as myoglobin, $20 \%$ stored in the form of ferritin and hemosiderin and $1 \%$ in enzymes (Viola, 2006). The daily doses required for some species are: swine $80 \mathrm{mg}$, adult dog $0.65 \mathrm{mg}$, marten $20 \mathrm{mg}$ and rodents 25 to $140 \mathrm{mg}$.

The state of the gastrointestinal tract of a given individual and the iron concentration in their diet influence iron homeostasis, which, unlike other minerals, is the only element regulated by absorption rather than by excretion. Organisms lose very little iron, with the quantity excreted through the feces representing almost exclusively the iron that is not absorbed from the diet. Even in the process of erythrocyte destruction (half-life of 6 to 12 weeks) in vertebrates, the hemoglobin fraction containing iron disintegrates into iron compounds and bilirubin, which are transported to the liver and eliminated through the bile. Iron, however, can be reused for the formation of hemoglobin, almost without loss (Andriguetto et al., 1988).

In the present study, significant differences in serum iron levels were neither observed between the inoculated and non-inoculated groups, nor between the periods before and after iron sulfate supplementation. This data suggests that circulating $\mathrm{Fe}^{3+}$ ions occur at low concentrations, probably because they are sequestered for the formation of hemoglobin molecules, which were found in significantly greater concentrations in both groups after iron sulfate supplementation.

Wallach and Boever (1983) and Lewis and Doyle (1964) reported mean hematocrit values for nine-banded armadillos of $32.2 \%$ and $42.5 \%$, respectively. In Brazil,
Souza et al. (1987a) found mean hematocrit values of $40 \%$ for males, $45 \%$ for females, $40 \%$ for recently inoculated armadillos and $44 \%$ for recently captured armadillos. Souza et al. (1987b) determined lower serum iron levels in armadillos inoculated with $M$. leprae (mean of $30.9 \mu \mathrm{g}$ ) and higher values (mean of $39.8 \mu \mathrm{g}$ ) for wild armadillos, while comparing wild armadillos with those inoculated with $M$. leprae. The authors also determined hemoglobin levels of $17.1 \mathrm{~g}(\%)$ for males and $16.0 \mathrm{~g}(\%)$ for females (Souza et al., 1987a). Garcia-Navarro and Pachaly (1994) reported 4.0 to $7.0 \times 106$ erythrocytes. $\mu \mathrm{L}^{-1}$, together with hematocrits of $32.2 \%$, hemoglobin of $11.2{\mathrm{~g} . \mathrm{dl}^{-1}}^{1}$ and 10 to $20 \times 103$ leukocytes. $\mu \mathrm{L}^{-1}$ in wild armadillos. The leukocyte counts in our samples were significantly lower than those reported by the authors cited above, suggesting a better health status of the captive armadillos studied here, probably due to feeding, de-worming and lower exposure to pathogenic microorganisms and parasites.

Hematocrits prior to iron sulfate supplementation were below $40 \%$, which showed probable anemia due to iron deficiency. In four of the inoculated armadillos, hematocrits were well below the values found in the literature, varying between 17 and 20\%, suggesting chronic disease anemia, since in this type of anemia iron is sequestered by the mononuclear phagocytic system (MPS). After iron sulfate supplementation, hematocrit values increased significantly in both groups, inoculated and non-inoculated, except for one inoculated armadillo that was showing signs of generalized lepromatous leprosy.

It is difficult to compare hematological values of armadillos because the reported studies were carried out under different conditions. It was not possible to compare the blood values with hematological data of wild individuals due to the fact that samples from free-roaming wild armadillos were not collected for the present study. Similarly, it is not possible to determine whether inoculation with $M$. leprae is the only determining factor for the anemia found in these animals. Since these armadillos did not receive vitamin $\mathrm{k}$ supplementation, the possibility of having anemic animals because of minor bleeding generated from vitamin $\mathrm{k}$ deficiencies can not be discarded (Superina, 2000). It is also possible that the feed provided for these armadillos in captivity over an extensive period is not well-balanced and thus does not allow maintaining sufficient bioavailable iron for its normal functions, leading to anemia.

Since $D$. novemcinctus develops leprosy in its generalized form, the chronic state of anemia, common in patients (Freitas and Fleury, 1996), could also affect experimentally infected armadillos and could be related to the dissemination of M. leprae. Anemia in chronic disease leads to the limitation of available iron for erythropoiesis. Under inflammatory conditions, the elevation of erythrophagocytosis by macrophages, an increase in the transportation of divalent metals and the reduction of ferroportin occurs, leading to the retention of iron by these cells. The need for iron in the proliferation of microor- 
ganisms also causes a reduction in the available iron. The production of bacterioferritin by $M$. leprae and the presence of sequences in its genome that are regulated by iron, indicate the importance of this biometal in its metabolism (Pessolani et al., 1994; Momotani et al., 1992). The disease alters iron metabolism by diverting it towards the intracellular medium, thus favoring M. leprae, which is an intracellular pathogen. This alteration could also be involved in the host immune response and in bacilli multiplication.

In all microcytic anemia, whether resulting from nutritional deficiency or due to disease (chronic disease anemia), the red blood cells are smaller with lower hemoglobin concentration than normal. This represents a diminished relation between red blood cells and plasma, resulting in lower than normal hematocrit values. The available iron is insufficient for the formation of hemoglobin. Erythrocyte production continues normally, though with the diminished availability of hemoglobin, these suffer a further division, consequently ending up smaller before reaching the reticulocyte phase $(75 \%$ of the content of hemoglobin).

Iron deficiencies due to inflammatory and/or infectious diseases result in lack of iron availability and impair formation of hemoglobin. This can be reversed with the ingestion of greater quantities of iron. Deficiency diminishes, improving the general health of the animal. Dietary supplementation with iron sulfate showed good retention of iron and its incorporation into hemoglobin (McDowell, 1992; Viola, 2006).

In conclusion, the dietary iron supplementation was satisfactory, important for iron metabolism and the maintenance of the armadillos in captivity, since a significant improvement in hematological levels occurred, both in inoculated and non-inoculated animals. Additional research is required for D. novemcinctus armadillos, so that they can be more adequately maintained not only in research institutes, but also in zoological gardens, aiming at improved captive conditions and increasing survival of armadillos outside their natural environment.

Acknowledgements - The authors would like to thank Cassia Maria Assis Pinke, laboratory technician of the ILSL, for processing the blood samples and Dr. Dirceu Dalpino, clinical pathologist of the ILSL, for his criticisms and suggestions during the development of this work.

\section{References}

ANDRIGUETO, JM., PELLY, L., MINARDI, I., GEMEAL, A., FLEMMING, JS., SOUZA, GA. and BONA-FILHO, A., 1988. Nutrição Animal. In As Bases e os Fundamentos da Nutrição Animal: Os Alimentos. 4. ed. São Paulo: Livraria Nobel. 425p.

ARRUDA, OS. and OPROMOLLA, DVA., 1981. Manutenção de Tatus em Cativeiro (Mammalia, Edentata). Revista Biotérios, vol. 5, p. 57-62.

BAGAGLI, E. SANO, A., COELHO, KI.,ALQUATI, S., MIYAJI, M., DE CARMARGO, ZP., GOMES, GM., FRANCO, M. and MONTENEGRO, MR., 1998. Isolation of Paracoccidioides brasiliensis from armadillos (Dasypus novemcinctus) captured in an endemic area of paracoccidioidomycosis. Am. J. Trop. Med. Hyg., vol. 58, no. 4, p. 505-512.

DINIZ, LS., COSTA, EO. and OLIVEIRA, PM., 1997. Clinical Disorders in Armadillos (Dasypodidae, Edentata) in Captivity. J. Vet. Med., vol. 44, no. 10, p. 577-582.

FREITAS, TC. and FLEURY, RN., 1996. Perfil Hematológico de Pacientes de Hanseníase com Episódios Reacionais de Eritema Nodoso. Hansen. Int., vol. 21, no. 1, p. 52-57.

GARCIA-NAVARRO, CEK. and PACHALY, JR., 1994. Manual de Hematologia Veterinária. 1 ed. São Paulo: Editora Varella, p. 145 e 169.

GARDNER, AL., 2005. Order Cingulata. In WILSON, DE. and REEDER, DM. (Eds.). Mammal Species of the World. 3. ed. Baltimore: John Hopkins University Press. MD. 2 vol, 2141 p.

KANEKO, JJ., 1980. Clinical Biochemistry of Domestic Animals. 3 ed. London: Academic Press, INC. p. 649-664.

LAGUNA, AF., 1984. El Cachimano Sabanero-aspectos de su biología y ecología. Caracas: Fondo editorial. 137 p.

LEWIS, JH. and DOYLE, AP., 1964. Coagulation, Protein and Cellular Studies on Armadillo Blood. Comp. Biochem. Physiol., vol. 12, p. 61-66

MACEDO, RCL., 1999. Paracoccidioides brasiliensis Infecção natural em tatus. Estudo em Serra da Mesa, Goiás, Brasil. In Proceedings da VII International Meeting on Paracoccidioidomycosis, Campos do Jordão. São Paulo: Universidade Federal de São Paulo, Escola Paulista de Medicina.

McDONOUGH, CM. and LOUGHRY, WJ., 1997. Influences on activity patterns in a population of nine - banded armadillos. J. Mammalogy, vol. 78, no. 3, p. 932-941.

McDOWELL, LR., 1992. Minerals in Animal and Human Nutrition. San Diego, CA: Academic Press. 524 p.

MOMOTANI, E., WUSCHER, N., RAVISSE, P. and RASTOGI, N., 1992. Imunohistochemical identification of ferritin, lactoferrin and transferrin in leprosy lesions of human skin biopsies. J. Comp. Pathol., vol. 106, no. 3, p. 213-20.

NAIFF, RD., FERREIRA, LC., BARRETT, TV., NAIFF, MF and ARIAS JR., 1986. Paracoccidioidomicose enzoótica em tatus (Dasypus novemcinctus) no estado do Pará. Rev. Inst Med. Trop. S. Paulo, vol. 53, no.1, p. 19-27.

OPROMOLLA, DVA., ARRUDA, OS. and FLEURY, RN., 1980. Manutenção de Tatus em Cativeiro Resultados de Inoculação do Mycobacterium leprae. Hansen. Int., vol. 5, no. 1, p. 28-36.

PEDRINI, SCB., ROSA, PS., BAGAGLI, E. and LOPES, CAM., 2006. Search for Mycobacterium leprae and other mycobacteria in wild armadillos. J. Venom. Anim. Toxins incl. Trop. Dis., vol. 12, no. 4, p. 675.

PESSOLANI, MC., SMITH, DR., RIVOIRE, B., McCORMICK, J., HEFTA, SA., COLE, ST. and BRENNAN, PJ., 1994. Purification, characterization, gene sequence, and significance of a bacterioferritin from Mycobacterium leprae. J. Exp. Med., vol. 180 , no. 1, p. 319-27.

ROSA, PS., BELONE, AFF., SILVA, EA., PEDRINI, SCB. and PINKE, CAE., 2005a. Inoculação experimental de tatus com M. leprae. Resultados Preliminares. Hansen. Int., vol. 30, no. 1, p. 120. 
ROSA, PS., BELONE, AFF. and SILVA, EA., 2005b. Reação de Mitsuda em tatus Dasypus novencimctus utilizando antígeno humano e antígeno derivado de tatus. Hansen. Int., vol. 30, no. 2 , p. 174-179.

ROBBINS, CT., 1992. Wildlife Feeding and Nutrition. 2 ed. New York: Elsevier Academic Publisher. 352 p.

SAXENA, N., SHARMA, RP., SINGH, VS., 1990. Serum Iron and Total Binding Capacity in Leprosy Patients. Ind. J. of Lepr., vol. 62 , no. 2 , p. $219-222$

SILVA-VERGARA， ML., 1997. Contribuição ao estudo epidemiológico da paracoccicioidomicose. Estudo em área agrícola de café. Rev. Soc. Bras. Med. Trop., vol. 30, p. 83-6.

SOUZA, LCD., DALPINO, D. and COSTA, HC., 1987a. Avaliação hematológica em tatus (Dasypus novemcinctus) capturados na cidade de Bauru - SP. Salusvita, vol. 6, no. 1, p. $79-88$

SOUZA, LCD., ARRUDA, OS., COSTA, HC. and ABREU, MFP., 1987b. Parâmetros bioquímicos do tatu (Dasypus novemcinctus); tatus silvestres e inoculados com Mycobacterium leprae. Salusvita, vol. 6, no. 1, p. 16-19.

STORRS, EE., 1971. The nine-banded armadillo: a model for leprosy and other biomedical research. Int. J. Lepr. Other Mycobact. Dis., vol. 39, no. 3, p. 703-714.

STORRS, EE. and BURCHFIELD, HP., 1985. Leprosy in common long - nosed armadillo Dasypus novemcinctus. In MONTGOMERY, GG. (Ed). The Evolution and Ecology of Armadillos, Sloths and Vermilinguas. Washington, DC: Smithsonian Institution Press Corporation. p. 265-268.

STORRS, EE., WALSH, GP., BURCHFIELD, HP. and BINFORD, CH., 1974. Leprosy in the armadillo: new model for biomedical research. Science, vol. 183, no. 127, p. 851-852.

SUPERINA, M., 2000. Biologie und Haltung von Gürteltieren (Dasypodidae). Switzerland: University of Zurich. 250 p. [Doctoral Thesis].

TRUMAN, RW. Leprosy. In VIZCAÍNO, SF. and LOUGHRY, WJ. (Eds.). The Biology of the Xenarthra. Gainesville, FL: The University Press of Florida. In press.

VERGARA, ML. and MARTINEZ, R., 1999. Role of the armadillo Dasypus novemcinctus in the epidemiology of paracoccidioidomycosis. Mycopath., vol. 144, no. 3, p. $131-133$

VIOLA, ES. 2006. Deficiências de Microelementos: Enfoque Metabólico e Nutricional. [16 nov., 2006]. Available from: www6.ufrgs.br/bioquimica/posgrad/TMAD/oligoelementos. pdf.

WALLACH, JD. and BOEVER, WJ., 1983. Edentates. In WALLACH, JD. and BOEVER, WJ. (Eds.). Diseases of Exotic Animals - Medical and Surgical Management. Philadelphia: Saunders. p. 612-629.

WETZEL, RM., 1985. Taxonomy and Distribution of Armadillos, Dasypodidae. In MONTGOMERY, GG. (Ed.). The Evolution and Ecology of Armadillos, Sloths and Vermilinguas. Washington, DC: Smithsonian Institution Press Corporation. p. $23-46$ 